\title{
Some Entrepreneurship Pitfalls
}

Philip Wolitzer

$A$ Il of us have at some point thought bow great it would be to be the boss of our own destiny and build a new business. For some it's a dream that won't stop until we try. In the old days, all it would bave taken was two months' rent after we built our leasebold improvements. Oh, bow times have changed.

To be the boss of your own business today you have to be aware of local, state, and federal regulations as well as the permits necessary for the type of business you are starting.At the minimum, you need an insurance advisor, a lawyer and a Certified Public Accountant (CPA). In some cases you may also need an architect, an interior decorator, and a communication or other specialist.

In 1494, Fra Luca Pacioli, a monk, wrote a treatise that established the bookkeeping practices still used today. In 1896, New York State passed a law that established the CPA license. Since then most enterprises found that they are better off paying attention to their business and leaving the accounting aspects to the accountants.

Small businesses have long resisted the expense of hiring an expert accountant. However, as even small businessowners have discovered, conducting a business today can become very complex and a CPA on retainer is a necessary expense.

Gone are the days when you could go into business with the necessary capital of two months rent and a deposit with the electric company. Today you have to worry whether you need

- Local permits

- Various other permits as necessary (restaurant, etc.)

- Building permits

- State approval (especially if you will be operating as a corporation or an LLC)

- Workers compensation

- Regular insurance (fire, liability, boiler, etc.)

- Business interruption insurance

- Rent security deposit

- Leasehold improvements

- Contracts for waste removal, etc.

- Special wiring for security

- Registration for sales tax, payroll tax returns, etc.

- Special bank accounts

- Other items necessary for specialized businesses

Fortunately, the accounting profession has approximately 350,000 CPAs practicing in the United States, including approximately 33,000 practicing in New York State.The problem for the small businessowner is how to choose the CPA who would be the best fit for them and their business.

To avoid pending bankruptcy, it is very important to set up an initial budget that gives the budding entrepreneur an idea of the capital necessary to succeed in the business. The most common cause of bankruptcy is insufficient capital to supply the cash needed for operation. Generally, poor planning can cause the closing of a new business within two years.

CPAs usually offer their services in practice units ranging from an individual practitioner to an employee of a very large firm, practicing on a global basis and having more than 100,000 employees. There are approximately 45,000 CPA firms practicing in the United States. The small businessowner should seek recommendations from friends, business associates, lawyer, bankers, and a professional association such as the New York State Society of Certified Public Accountants. There is no harm in interviewing three or so CPAs to decide who would be a good advisor. It should be remembered that a CPA is a professional who has spent many years acquiring his or her educational background and practical experience and thus commands professional fees. It has been my experience that the benefits of the CPA far exceed the cost.

Personal recommendations from friends, your banker, and your lawyer should form the basis of your choice of an accountant. Choose a Certified Public Accountant-they hold a license to practice from the state and have the required education and experience. They are professional and you should expect to pay them professional fees.

However, the benefits can be great. You can concentrate on running your business and expanding your business without worrying too much about the financial aspects. The CPA can help with budgeting, the practical aspects of running the business and reporting the results. The CPA can also file all the necessary tax returns to the local, state, and federal authorities. The banker wants to see financial statements and creditors also want financial information. The CPA exemplifies the benefit side of the cost-benefit ratio.

At the outset, until the business gets on its feet, the CPA will probably do everything:

- The bookkeeping of all the books of account

- Filing of all applications necessary to local and federal agencies

- Filing all necessary tax returns 
- Answering mail where the businessowner needs advice

- Helping with inventory allocation and management

- Assisting with credit decisions

- In general, advising and being a business resource

The businessowner and the CPA should have good chemistry between them, otherwise, their means of communication will become strained.The small businessowner will find the telephone, fax machine, and e-mail the most common form of communication with his or her professional advisor. He or she must remember however, that even though the business has only one CPA, the CPA may be responsible for as many as 100 other clients.

Of the approximately 20 million small businesses in the United States, only two-thirds of the start-ups go past the twoyear mark and only 44 percent go past four years. It is very important, therefore, that the entrepreneur and the CPA agree on a detailed business plan with adequate start-up capital. If the businessowner does not have practical experience in the field, he or she should consider the purchase of an established business. At this point, the budding businessowner may come in for a sudden shock. For instance, assume the starting capital necessary is $\$ 500,000$, the minimum numbers of hours to run the business is 60 hours a week, and the owner will net approximately $\$ 60,000$. A fast calculation then tells you that if you invested $\$ 500,000$ without risk, it would earn approximately 5 percent or $\$ 75,000$ a year. If you took a job where someone else is assuming all the risks and earned approximately $\$ 10$ an hour minimum, earning approximately $\$ 30,000$ a year (plus benefits), you can then make a comparison whether starting the business is worth while. Just think of the comparison if you can now earn \$20 or $\$ 30$ an hour. In business you assume all the risks of losing $\$ 500,000$. As an employee, you assume no risk and your net income is approximately equal to your business revenue. It is a bad comparison since we are not factoring in the psychic benefits of owning your own business so that it will throw off much more that $\$ 60,000$. Always remember the business should be run to satisfy your customers, not to make you feel good. Good market research does not have to eat big money.

... So you want to be the master of your own fate.To ensure success, bring in an attorney and an accountant at the "thinking stage" and not after you have made most of your decisions. Under the cost-benefits ratio, your success is accelerated when you bring in your advisors during the early stages.

The CPA can be very helpful in making sure the business remains viable and soundly capitalized.The CPA is usually well equipped to be a well-rounded business advisor and his years of experience enable him to call on other professionals as the need arises. For instance, the CPA cannot practice law and his knowledge of life and business insurance may be limited.

Profitability is important for every business. Small business-owners seem to have great problems in maintaining liq- uidity. Part of the problem is insufficient capital. Small businesses will find that owners' capital has to be sufficient to carry accounts receivable, inventory, and capital assets. The larger the business, the more it can utilize creditors equity as well as owners equity.

While keeping competition in view, the use of adequate gross margins is very important. Everyone wants to increase sales by lowering prices, but sometimes less can be more.You have to be very careful that gross margins do not suffer as sales are increased. The business graveyard is replete with companies that felt they could sacrifice gross margins to increase sales. They forget that the gross margin has to cover all expenses as well as net income for the owners.

The assistance and support of the CPA becomes essential to avoid bankruptcy. Remember, asking for advice is not a sign of weakness. The CPA is very familiar with the need of adequate gross margins, cash flow, and the need to stay within the law. Cash laundering can be very tempting but it is also illegal. Sacrificing margins sounds great but not at the expense of experiencing cash flow problems

It is very important that the CPA explain to the entrepreneur the relationship of the Income Statement on the accrual basis to the Statement of Cash Flows, which is on the cash basis. It is not an easy concept to comprehend.

The businessowner may be surprised to find that he can ask the CPA for help in not only accounting, auditing, and tax matters, but also for help in

- Trust and estate planning

- System design and implementation

- Information technology

- Risk assessment

- Insurance reviews

- Financial planning including retirement

- Mortgage planning

- Asset protection

- General business planning

- Succession planning

- Business formation (corporation, partnerships, etc.)

- Financing assistance

- General business management

The small businessowner will achieve the greatest success in choosing a CPA who is on his or her own, or is a member of a small partnership. That way the entrepreneur can be assured of personal attention as well as reasonable fees. The businessowner will be best served by a CPA who can be his or her trusted business advisor and act as a wise sounding board.

Professionally prepared financial statements by a CPA can act as the solid base for the businessowner.The creditors and the bankers can use them to assess the viability of the business as well as setting credit limits. The businessowner and the CPA working together can make a formidable team to ensure the success of the business enterprise. 


\section{About the Author}

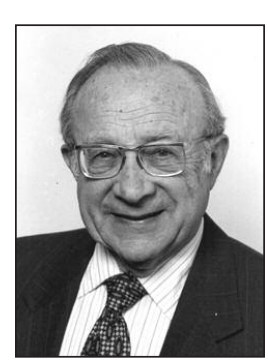

PHilip Wolitzer has been associated with the Long Island University, Brooklyn Campus School of Business, Public Administration and Information Sciences for more than 60 years. He began his teaching career as an instructor in 1946 and served as chair of the department of accounting from 1964 to 1983. During this time he was promoted to the rank of full professor. Prof. Wolitzer served as the director at the business game and the venture capital game at the Brooklyn Campus from1970 to 1982. In 1998, the university honored him by dedicated a portion of the Humanities Building, 7th floor as the Philip Wolitzer Complex.

Throughout his distinguished career, Prof. Wolitzer has served as faculty advisor to the student Accounting Society at the Brooklyn Campus, as an officer and member of the faculty organizations and instituted the internship program for accounting students. He has been a financial consultant to many businesses and has been actively involved in the Foundation for Accounting Education and the New York State CPA Society, and has been elected to the organization's Hall of Fame. Prof. Wolitzer was named Outstanding Educator of America in 1971 .

A member of the American Institute of Certified Public Accountants, American Accounting Association, American Association of University Professors, and Accountants Club of America, where he has served as a member of the board as well as secretary and president, Prof. Wolitzer is also active in civic and charitable works. He has been fund chair for the United Hospital Campaign, Greater New York Fund and the Leukemia Society. The author of numerous papers and articles, he is also a popular and sought-after speaker by professionals groups.

Prof. Wolitzer earned his BBA degree at the City College of New York and his MBA at New York University-both with honors. He was elected to Beta Gamma Sigma as an undergraduate. 